\title{
International Portfolio Diversification: A Practical Approach to Wealth Management
}

\author{
Marcin Halicki, Andreas Uphaus*
}

\begin{abstract}
Purpose - Showing that the current international portfolio diversification in the era of globalization is a useful tool that allows building an investment portfolio offering relatively high rates of return (which is approved as a benchmark) with an acceptable risk.

Design/methodology/approach - Literature research and the empirical studies of companies' share prices. Findings - The presented investment strategy of stock selection from different countries will surely be a positive factor for the results of portfolio management.

Originality/value - Study that showed the way to obtain above-average returns. The presented in the paper method of stock choice is effective and simple to use and to explain.
\end{abstract}

Keywords: portfolio decisions, stock markets, international investments, portfolio rebalancing, stock index

\section{Introduction}

Today the wealth management industry begins to experience serious problems with the recent financial and banking crisis and uncertainty currently prevailing in the financial markets. The crisis, beginning in 2007, was mainly the result of bad decisions by banks, which reached large profits before the crisis, and encouraged them to achieve even more profit by using leverage at the expense of the mismatch between assets and liabilities (Cabral 2013). The result is a fairly significant decline in the value of assets managed by the largest private banks in the world (Scorpio Partnership 2012). So, it is worth considering the question whether under such conditions a new method can be used that allows wealth management business to attract new customers and maintain permanent ones. One of these tools could be international equity portfolio diversification. It involves the construction of a portfolio of shares containing companies from different countries. The portfolio analysis is based on historical data and requires the share price to reflect the most important information for investors. However, historical data does not contain information about future volatility and correlation (Longin, Solnik 1995), which may result in additional transaction costs in the context of rebalancing portfolios.

\footnotetext{
"PhD in Economics, Marcin Halicki, University of Rzeszów, Aleja Rejtana 16c, 35-959 Rzeszów, mhalicki@ur.edu. pl; Professor Doktor rer. pol., Andreas Uphaus, Bielefeld University of Applied Sciences, Universitätsstraße 25, 33615 Bielefeld, Germany, andreas.uphaus@fh-bielefeld.de.
} 
Though, portfolio analysis in the era of globalization is still used in practice, because of the proper selection of the companies within the portfolio, it does not have to be rebalanced too often. It is known that the same international portfolio diversification is not a panacea for the problems associated with obtaining low rates of return. Therefore, the question of whether the current international portfolio diversification in the era of globalization is a useful tool that allows building an investment portfolio offering relatively high rates of return (which is approved as a benchmark) with an acceptable risk should be answered. The answer to this question is the main goal of this paper. The presented approach can be assessed as attractive for clients of the wealth management industry after the financial crisis. A second goal of this paper is to present an effective and simple method of stock selection, based on real data and without short sale. Unfortunately, most publications which present research on international diversification only show the relationship between market indices (eg. Longin, Solnik 2001) without research on single stocks or portfolios. However, this approach does not present an added value for the client wealth management industry, as the indices do not reflect the performance of investment portfolios and specific correlation between companies of different countries. In this publication the following research methods were used: literature research and empirical studies of companies' share prices.

\section{General characteristic of international diversification}

International portfolio diversification is an issue that often arouses controversy. It is worth noting that the literature devotes little space to the issue of international diversification, because investors often prefer to invest in domestic stocks, rather than external ones (Coval, Moskowitz 1999). This behavioural effect is often called home bias. This might be caused by the discrepancy between the theory and practice of investment, as well as by changes in exchange rates, which might significantly affect the rate of return derived from the portfolio consisting of domestic and foreign securities. Additionally, there can be found some studies that support the small benefits of international diversification (Das, Uppal 2004), because the rate of return on international equities is characterized by sudden changes that occur simultaneously and contribute to incurring high risks. It should be noted that these studies were carried out in the 1980's and 1990's, when the global economic situation was very different from today. But more recent studies (Bekaert et.al. 2009) have shown that the process of globalization has not led to major changes in the structure of the correlation of securities on international stock markets. Nevertheless, already in the 1960's and 1970's one can find attempts to study the international diversification of portfolios (Grubel 1968; Levy, Sarnat 1970; Grubel, Fadner 1971; Lessard 1973; Solnik 1974). It is known that the purpose of international diversification should be to reduce the risk of the investment portfolio consisting of various securities listed on foreign exchanges. However, one problem of the construction of a portfolio consisting of foreign shares may be business cycles in the stock market, yet the capital markets are still subject to changes, which is obvious simply looking at the behaviour 
of indices. Moreover, rebalancing can contribute to a low rate of return and it is possible in such a situation that the uncorrelated shares will be listed in countries with low transparency, which admittedly would obtain large benefits of international diversification, but also it so happens that funds prefer transparent countries (Gelos, Wei 2005). This means that international diversification in portfolio management practice could lead to problems with the selection of the countries in which one would like to acquire shares.

\section{The model}

The most important variables taken into account by investors are the following (Chan et.al. 2005): economic development, capital control, stock market development, familiarity ${ }^{1}$ as well as investor's protection and other variables (e.g., rate of return). These factors seem to be very important in the selection of target markets for investments. The selection should answer the question, how many markets should be selected using the previously mentioned criteria and which the weight of each of the selected markets should be. So, the following rule is proposed: select only 2 or even a few markets, select only stocks of the major index of each country as investment opportunities, the number of securities should be restricted adequately, the weight of each market should be measured as number of securities, choose securities for each country in relation to the number of stocks in the major index of each market. Or more general: Let $M$ be the number of markets taken into account and $I_{m}$ the number of shares in the major index of market $m(m \in\{1, \ldots, M\})$. Furthermore $N$ should denote the maximal number of securities chosen overall. Hence, $n_{m}=\left[N \times \frac{I_{m}}{\sum_{j=1}^{M} I_{j}}\right]$ should be the maximum number of stocks selected from market $\mathrm{m}$. The formation of the portfolio and therefore the selection of securities in this model are done in two steps. In the first step at maximum $N$ securities of the $M$ markets with the highest returns are selected. This step is implemented in this model to reduce the complexity of the general problem and to focus on the most important investment opportunities in the selected markets. In a second step a portfolio is built which performs equal or better than the benchmark. To reduce complexity securities have to qualify for the portfolio. This qualification is based on returns. But how should returns be measured? While the return in period $t$ is typically defined as $R_{t}=\left(P_{t}-P_{t-1}\right) /\left(P_{t-1}\right)$ where $P_{t}$ is the ending price of a security of period $t$, the question is still which proper length of a period and a proper statistical figure could it be? The economic challenge in this context is that during and after the financial crisis the returns were very volatile so that a simple two point in time calculation consisting of one price in the beginning and one at the end of a period seems not to reflect the real market situation. Without the loss of generality it is assumed that a proper return period length $\Omega$ is one year. A typical

\footnotetext{
tion.

${ }^{1}$ Investors are worse informed about foreign markets, so they have to bear higher costs of acquiring informa-
} 
statistical measure is an average of return, e.g. using monthly returns for one year. But because of the high volatility a more robust measure which shows the return tendency in an adequate manner too, seems to be more feasible. Therefore the qualification criterion should be the return tendency for each security $\mathrm{i}$ and formation period $\mathrm{t}$ defined as $\tilde{R}_{i, t} \cdot \tilde{R}_{i, t}$ is calculated using the slope $\beta_{i, t}^{1}$ of the regression function of the returns of this period defined as $\tilde{r}_{t}^{\tau}=\beta_{i, t}^{0}+\beta_{i, t}^{1} \times \tau+\varepsilon_{\tau}$, where $\tau=1, \ldots, \Omega$ is the time index of the shortest observed period or tic period $\pi$ (typically one month), $\varepsilon_{\tau}$ as an error term and $\beta_{i, t}^{0}$ as an intercept. $\beta_{i, t}^{1}$ is estimated so that the estimate for $\tilde{R}_{i, t}=\hat{\beta}_{i, t}^{1}$. The securities of each market $\mathrm{m}$ are ranked by $\tilde{R}_{i, t}$ of each security. The $n_{m}$ securities $i$ with the highest return $R_{i, t}$ in each market m qualify for the formation of the portfolio ${ }^{2}$.

Now knowing which securities could be part of the wanted portfolio, as a next step the weights of each security have to be derived. This is still depending on an adequate benchmark. Surely, the best benchmark of an investment strategy is the theoretical optimum over the worldwide investment opportunity set. But while this theoretical measure is always not available, another performance measure should be discussed. While the basic idea of international investments is still to perform better than in national investments, the benchmark in the context of this article should be the index of the strongest or higher capitalized of the previously chosen markets. There exist two possibilities for benchmarking. First, comparing returns while risk is given. Second, comparing risk while the return is given. The first possibility is preferred in this context because it is the most common question of how to maximize a return.

As it was mentioned, the purpose of this publication is to present a method of portfolio formation, so that a portfolio consists of shares of the markets chosen before and which would achieve high rates of return (relative to the selected benchmark ${ }^{3}$ ). Hence, such portfolios should be efficient portfolios. To determine the effective set, it is necessary to apply a model linear programming, in which both, the constraints and the objective functions, are linear. Linear programming is used in order to achieve the best results for mathematical functions under certain restrictive conditions (Chen et al. 2012). The conditions of linear programming in the research context are:

Objective function:

$$
R p=\sum_{i=1}^{N} w_{i} \times R_{i} \rightarrow \max
$$

where:

$R_{p}$ - the expected rate of return on the portfolio consisting of selected shares,

$w_{i}$ - percentage of the $i$-th companies in the portfolio,

$R_{i}$ - expected rate of return on rate-shares and the company,

$N$ - number of shares in the portfolio.

\footnotetext{
${ }^{2}$ The qualifying procedure is similar to that of De Bondt and Thaler (1985).

${ }^{3}$ Under the practical assumption of no short selling.
} 
Restrictions:

$$
S_{p}=\sqrt{\sum_{i=1}^{n} w_{i}^{2} \times S_{i}^{e}+\sum_{i=1}^{n} \sum_{j=1}^{n} w_{i} \times w_{j} \times s_{i} \times s_{j} \times \rho_{i j}}=\alpha, \quad i \neq j
$$

where:

$S_{p} \quad-$ the standard deviation of the portfolio functioning as a measure of the risk, which at the assumed possible level is to allow for a maximum rate of return of the portfolio,

$s_{i}^{2}, s_{j}^{2}-$ the variance of the $i$-th $(j$-th) shares in the portfolio,

$\rho_{i j} \quad-$ correlation coefficient of returns of $i$-th and $j$-shares of the stock,

$\alpha \quad-$ level of risk of benchmark in the same period (in the research it was rarely small low or high). The benchmark was an index,

$0 \leq w_{i} \leq 1$,

and

$\sum_{i=1}^{\mathrm{n}} w_{i}=1$.

The method of linear programming, which was designed to maximize the rate of return of the portfolio, took into account the presented constraints, abandoned in short selling. But another problem has to be solved in this context: While the portfolio was not only built of securities of the major index of one country and on the other hand negative returns are possible, there may exist portfolios or even single securities that may dominate the before calculated optimum. If this is the case, the security $i$ has to be selected that fulfills the condition

$R_{i} \rightarrow \max$ and $S_{p} \cong \alpha$. On the other hand, the situation might occur where there is no portfolio better than the benchmark. In this case the investment amount is held in cash. If a long term investment over several years is intended, continuous rebalancing seems to be considerable. If the overall period is $T$, rebalancing is typically done in equidistant subsequent time periods. The rebalancing period could be denoted as $L=l \times \pi$ with 1 as the number of tic periods within the rebalancing period. After each period $L$ the portfolio is rebalanced again. The strategy is successful, if risk is equal to the benchmark (or a little more) and the return is higher than the benchmark. This is fulfilled by definition of the aforementioned process. The question is still which the difference might be.

The model was tested using an exemplary empirical study. The assumptions of the construction of the portfolio were as follows:

1) In order to justify the validity thesis of the international portfolio diversification concept from a practical perspective of wealth management, it was a hypothetical investment conducted: for a period of five years there was invested an amount of approximately EUR 1,000,000.

2) The study should focus on $M=2$ markets.

3) While the method of Markowitz (Markowitz 1952) is typically based on a long term holding period, the minimum investment period is admittedly one month, but the total investment period should be $T=60$ months (5 years). 
4) An investment decision is made on the basis of rates of return calculated over the past 12 months. So, $\pi=1$ month and $\Omega=12$.

5) The portfolio rebalancing followed in three monthly intervals ( $l=3$ and $L=3$ months).

6) The portfolio should consist of $N=10$ shares.

7) Investment currency was Euro, which will reduce the currency risk of investments and, therefore, prices of shares in other countries were converted to the value of the Euro (exchange rate was taken from the closing date) if necessary.

8) Transaction costs and portfolio management costs are not integrated, as well as the purchase of foreign currency (in the research - Polish zloty).

The selection of countries and markets should be performed in a pragmatic manner, like described before, taking into account some general economic aspects. At first 2 markets should be chosen. As it is known, the economies of rapidly developing countries, which are included in the so-called "emerging markets", in the short run, have better growth prospects than the mature economies. This is because of higher consumption growth and a lower level of public debt (International Monetary Fund 2013). In this perspective, international portfolio diversification would allow for the construction of a portfolio consisting of mature companies listed on the stock exchange and which should be characterized by low risk, and the companies listed on the stock market rising and offering a high rate of return, but characterized by a relatively high risk. Such an approach would also allow independence from the stock market situation of a country, as well as maximizing the rate of returns for a given portfolio risk by the portfolio manager (client wealth management business).

It should be noted that the European Union is the only world's economic and political union of democratic countries, which includes mature and rapidly developing countries (currently it consists of 28 countries). Importantly, the EU law has primacy over national law (normative rules) of Member States (Europa.eu). The result is that the mature and rapidly developing countries are bound to implement the same legal solutions to facilitate the economic development of the latter, and also improves the safety and supervision of investment capital. So, in order to minimize the risk of the investment, and at the present time characterized by uncertainty in the financial markets, an attractive alternative for investors and the customers' wealth management industry would be a portfolio of shares listed on the German (mature) and Polish (growing) stock exchange securities. This choice can be justified by targeting the factors presented earlier (Chan et.al 2005). These factors related to the above mentioned countries, are presented in Table 1.

For international portfolio diversification, one recommendation could be to select specifically Germany and Poland for the reason that in the midst of all mature EU Member States Germany is the one with the largest economy, and the largest economy in the European Union within States of "emerging markets" is Poland. Moreover, these countries are characterized by moderate growth (Eurostat) and high political stability (Political Instability Index 2014) and a large number of people. Their stock exchanges have relatively high capitalization and the functioning of the capital markets is transparent. It is also important 


\section{Table 1}

Basic data of Poland and Germany

\begin{tabular}{|c|c|c|}
\hline Factor & Poland & Germany \\
\hline $\begin{array}{l}\text { People in } 2012 \text { (in thousands) } \\
\text { (United Nations Statistics Division, 2012) }\end{array}$ & 38,317 & 81,991 \\
\hline $\begin{array}{l}\text { Economic development } \\
\text { (GDP - 2013, millions of USD / place in the world) (World Bank, 2013) }\end{array}$ & $\begin{array}{l}525,866 / \\
23 \text { th }\end{array}$ & $\begin{array}{l}3,730,261 / \\
4 \text { th }\end{array}$ \\
\hline Capital control* $^{*}$ & very good & very good \\
\hline $\begin{array}{l}\text { Stock market development - domestic market capitalization } \\
\text { of the main stock exchange at month end, EUR millions } \\
\text { (Federation of European Securities Exchanges, December 2014) }\end{array}$ & $139,069.33$ & $1,436,728.68$ \\
\hline Familiarity* $^{*}$ & very good & very good \\
\hline Investor protection (Subjective evaluation as an example) & very good & very good \\
\hline $\begin{array}{l}\text { Rate of return of the main stock index } \\
(12.31 .2007-12.30 .2013) \text { (stooq.pl) }\end{array}$ & $\begin{array}{l}-0,26 \% \\
\text { (monthly, WIG20) }\end{array}$ & $\begin{array}{l}0,43 \% \\
\text { (monthly, DAX30) }\end{array}$ \\
\hline
\end{tabular}

that the selected countries belong to a single market, which is the lifeblood of European economies. Therefore it seems as if long-term investment in quoted shares in these countries is likely to offer a high rate of return. The names of the largest Polish and German shares included in their major indexes are listed in Table 2.

\section{Table 2}

The names of Polish shares included in the WIG 20 index and names of German shares included in the DAX 30 index

\begin{tabular}{rll}
\hline No. & Company name (DAX 30) & Company name (WIG 20) \\
\hline 1 & 2 & 3 \\
\hline 1. & adidas AG & Asseco Poland SA \\
2. & Allianz & Bank Handlowy w Warszawie SA \\
3. & BASF SE & BRE Bank SA \\
4. & Bayer & Boryszew SA \\
5. & Beiersdorf & Globe Trade Centre SA \\
6. & BMW AG & Jastrzębska Spółka Węglowa SA (not included) \\
7. & Commerzbank AG & Kernel Holding SA \\
8. & Continental AG & KGHM Polska Miedź SA \\
9. & Daimler AG & Grupa Lotos SA \\
10. & Deutsche Bank AG & Lubelski Węgiel Bogdanka SA (not included) \\
11. & Deutsche Börse AG & Bank Polska Kasa Opieki SA \\
12. & Deutsche Lufthansa AG & PGE Polska Grupa Energetyczna SA (not included) \\
13. Deutsche Post AG & Polskie Górnictwo Naftowe i Gazownictwo SA \\
14. Deutche Telekom AG & Polski Koncern Naftowy ORLEN SA \\
15. & E.ON SE & Powszechna Kasa Oszczędności Bank Polski SA
\end{tabular}




\begin{tabular}{rll}
\hline 1 & 2 & 3 \\
\hline 16. & Fresenius SE \& Co. KGaA (St.) & Powszechny Zakład Ubezpieczeń SA (not included) \\
17. & Fresenius Medical Care AG \& Co. KGaA & Synthos SA \\
18. & HeidelbergCement AG & Tauron Polska Energia SA (not included) \\
19. & Henkel KGaA Vz. & TELEKOMUNIKACJA POLSKA SA \\
20. & Infineon Technologies AG & TVN SA \\
21. & K+S AG & \\
22. & Linde AG & \\
23. & LANXESS AG & \\
24. & Merck KGaA & \\
25. & Münchener Rückversicherungs-Gesellschaft AG & \\
26. & RWE AG & \\
27. & SAP AG & \\
28. & Siemens AG & \\
29. & ThyssenKrupp AG & \\
30. & Volkswagen AG & \\
\hline
\end{tabular}

Source: own study based on the data of finanzen.net and Stooq.

So, the result of this qualification discussion is $M=2$ (Poland and Germany), the number of shares in the major indices is $I_{\text {Poland }}=20$ and $I_{\text {Germany }}=30, n_{\text {Poland }}=[10(20 / 50)]=$ and $n_{\text {Germany }}=6$. Surely, the shares in the index could change over time, but to simplify the approach only shares which have been part of the index at the end of a three month period were chosen. The research was started on 2 Jan 2009 and ended 30 Dec 2013. It is assumed that for the chosen German and Polish stock market liquidity and high efficiency is given. This allows for building the portfolio based on risk criteria and historical returns. It was assumed that the risk is measured by a standard deviation of returns, and the historical rate of return is the arithmetic average of the individual rates of return. The analysis included the shares belonging to the indices covering the largest and most liquid companies (Germany DAX30, Polish - WIG20), presented in Tables 2 and 3. Moreover, the practice of investing shows the problems arising from the calculation of the average rate of the stock return, and it is known that the banking and financial crisis that began in 2007 in the U.S., also created the collapse of financial markets in the European Union. For this reason, the study does not include the period till the end of 2007 , because the results would be abnormal. Thus, the average rate of return and the risk of Polish and German shares measured by the standard deviation were calculated for the period 31 Dec 2007 - 30 Sept 2013. The starting date for the calculation has to be the 31 Dec 2007 so that 12 monthly returns could be chosen to build up the first formation portfolio on 2 Jan 2009. It is also important that the investment took into account the exchange rate (open) EUR / PLN on the construction of the portfolio (and the acquisition of Polish shares) as well as the closing exchange rate on the date of the sale of Polish shares. The purchase prices of the shares were of course open, and after 3 months the sales prices were closing rates. The closing rates of shares and the Euro currency from every end of the month of that period were selected - in order to obtain more accurate data. Within 
the DAX, 30 shares were tested, while within the WIG20 - only 15 because not all of the 20 shares had belonged to the index before December 2007. Furthermore it is well-known that membership in the prestigious indices also affects the liquidity. The data were obtained from such financial portals as "finanzen.net" (Finanzen.net) and "stooq" (Stooq.pl).

While 12 returns are needed to build the first formation portfolio, the total research time is $T=60$ months ( 5 years) and for the last rebalancing period (no additional return calculation is necessary), 69 (= $T+\Omega-L$ ) return rates and standard deviations of return rate (for shares and for index) were computed. The stocks were characterized by the highest directional coefficients of the linear regression function returns for the last 12 months. So, the shares i of each market were chosen of which $\tilde{R}_{i, t}=\hat{\beta}_{i, t}^{1}$ were maximized. In the first formation these shares were: SNS, PKO, TVN and TPS from Poland as well as Allianz, Münchner Rück, Deutsche Post, Henkel, Siemens and Deutsche Telekom from Germany. The benchmark was defined as the major index of the stronger economy. Without a loss of generality it was assumed that the stronger economy in this context seems to be Germany. So, the benchmark index is the DAX. To find a portfolio which performs better than the DAX in a first step an efficient portfolio was built using the linear program shown above. A portfolio with the same risk than the Dax but a higher return consists of $89 \%$ TPS and $11 \%$ Münchner Rück only. But because of the mentioned efficiency aspects there existed another portfolio consisting only of Münchner Rück which has even a higher expected return and a lower risk $\left(S_{p}=\alpha\right)$. In summary, the first rebalancing of the portfolio was on 1 April 2009 and the last - on 1 Oct 2013. That means that the portfolios were built 20 times and thereof 19 times the rebalancing was done. The results obtained (assuming the benchmark as the DAX index) are presented in Table 3.

\section{Table 3}

Key figures of the conduct of investment and DAX

\begin{tabular}{lll}
\cline { 2 - 3 } & DAX & Portfolio \\
\hline Value on 2 Jan 2009 & $4,856.85$ & EUR 1,000,050.85 \\
Value on 30 Dec 2013 & $9,552.16$ & EUR 3,184,365.82 \\
The total rate of return & $96.67 \%$ & $218.42 \%$ \\
$\begin{array}{l}\text { The annual rate of return } \\
\text { Expected rate of return calculated on the basis of the average 3-month }\end{array}$ & $14.49 \%$ & $26.07 \%$ \\
$\quad$ & $3.96 \%$ & $6.94 \%$ \\
$\quad \begin{array}{l}\text { historical rates of return } \\
\quad \text { of the average 3-month historical rates of return }\end{array}$ & \\
Coefficient of a variation of 3-month historical data & $11.02 \%$ & $14.65 \%$ \\
\hline
\end{tabular}

Source: own development.

The data presented in Table 3 show clearly that using the proposed method of portfolio management, a rate of return on invested capital at the level of $218.42 \%$ was achieved. In this period the rate of return on the DAX index, which is the benchmark, was $96.67 \%$, which is 
much less. This means that the obtained investment results can be considered as satisfactory. In summary, in this example the proposed method of portfolio management within the international diversification can be recommended for use in practice.

\section{Conclusions}

Based on the literature and empirical research, the proposed method of international portfolio diversification might be an effective tool in getting customers in the wealth management industry. Of course, there is other recent research concerning investment strategy and based on fundamental data, analysts' expectations and momentum variables which is quite good in the long-run (Guerard et al. 2015). But there are several advantages of the proposed method: first and foremost, it extends the investment opportunity set and offers a greater choice of financial instruments than a national selection, which allows for the effective implementation of the investment strategy. Secondly, it offers the ability to match the target capital market investment preferences, knowledge and experience of the investor. Thirdly, reducing the investment risk with this method does not result only from the standard deviation, but even from the economies of the countries. Fourth, the transaction costs for efficient portfolio management should not limit the rate of return. Fifth, it allows analysing various capital markets for the commencement of the project and selects the index of one of them as a benchmark, which will be an indicator of a minimum level of profitability.

On the basis of scientific research it cannot be concluded unequivocally that in each case the choice of foreign shares will guarantee getting exceptional returns. However, a suitable investment strategy of stock selection from different countries will surely be a positive factor for the results of portfolio management. This is confirmed by the studies that showed the way to obtain above-average returns. It should be mentioned too, that the presented method of stock choice is effective and simple to use and to explain. Therefore, this portfolio theory based method seems to have a high potential for practical use in wealth management.

\section{References}

Bekaert G., Hodrick R.J., Zhang X. (2009), International Stock Return Comovements, "The Journal of Finance" vol. 64 , no. 6, pp. 2591-2625.

Cabral R. (2013), A perspective on the symptoms and causes of the financial crisis, "Journal of Banking \& Finance" vol. 37, pp. 103-117.

Chan K., Covrig V., Ng L. (2005), What Determines the Domestic Bias and Foreign Bias? Evidence from Mutual Fund Equity Allocations Worldwide, "The Journal of Finance" vol. 60, no. 3, pp. 1511-1522.

Chelley-Steeley P.L. (2005), Modeling equity market integration using smooth transition analysis: A study of Eastern European stock markets, "Journal of International Money and Finance" no. 24, pp. 818-831.

Chen B., Liou F.-M., Huang C.P. (2012), Optimal Financing Mix of Financially Non-Viable Private-Participation Investment Project with Initial Subsidy, "Inzinerine Ekonomika-Engineering Economics” vol. 23, no. 5, p. 455. 
Coval J.D., Moskowitz T.J. (1999), Home Bias at Home: Local Equity Preference in Domestic Portfolios, “The Journal of Finance" vol. 54, no. 6, pp. 2045-2073.

Das S.R., Uppal R. (2004), Systemic Risk and International Portfolio Choice, "The Journal of Finance" vol. 59, no. 6 , pp. 2809-2834.

De Bondt F.M., Thaler R. (1985), Does the Stock Market Overreact?, "The Journal of Finance" vol. 40, no. 3, pp. 793-805.

Europa.eu (2014), Brussels: European Union, http://europa.eu/index_en.htm (2.01.2014).

Eurostat (2014), European statistics. Luxembourg: Eurostat, http://epp.eurostat.ec.europa.eu/portal/page/portal/eurostat/home (2.01.2014).

Fama E.F., French K.R. (2008), Dissecting Anomalies, “The Journal of Finance” vol. 63, no. 4, pp. 1676.

Fama E.F., French K.R. (2010), Luck versus Skill in the Cross-Section of Mutual Fund Returns, "The Journal o f Finance" vol. 65, no. 5, pp. 1915-1947.

Federation of European Securities Exchanges-FESE, December 2014, Brussels: Federation of European Securities Exchanges, www.fese.eu/en (23.01.2015).

Finanzen.net (2014), Karlsruhe: finanzen.net GmbH. Available from: www.finanzen.net (2.01.2014).

Gelos R.G., Wei S.-J. (2005), Transparency and International Portfolio Holdings, "The Journal of Finance" vol. 60, no. 6, pp. 2987-3020.

Grubel H.G., Fadner K. (1971), The Interdependence of International Equity Markets, "The Journal of Finance" vol. 26, no. 1, pp. 89-94.

Grubel H.G. (1968), Internationally Diversified Portfolios: Welfare Gains and Capital Flows, "The American Economic Review" vol. 58, no. 5, pp. 1299-1314.

Guerard J.B., Markowitz H., Xu G, (2015), Earnings forecasting in a global stock selection model and

efficient portfolio construction and management, "International Journal of Forecasting" no. 31, p. 558.

International Monetary Fund (2013), World Economic Outlook - April 2013, Washington: International Monetary Fund. pp. 2-7, www.imf.org/external/pubs/ft/weo/2013/01/pdf/text.pdf (2.01.2014).

Lessard D.R. (1973), International Portfolio Diversification: A Multivariate Analysis for a Group of Latin American Countries, "The Journal of Finance" vol. 28, no. 3, pp. 619-633.

Levy H., Sarnat M. (1970), International Diversification of Investment Portfolios, "The American Economic Review" vol. 60, no. 4, pp. 668-675.

Longin F., Solnik B. (1995), Is the correlation in international equity returns constant: 1960-1990?, "Journal of International Money and Finance" vol. 14, no, 1, pp. 3-26.

Markowitz H. (1952), Portfolio Selection, "The Journal of Finance” vol. 7, no. 1, pp. 77-91.

Political Instability Index (2015), London: Economist Intelligence Unit. Available from: http://viewswire.eiu.com/ site_info.asp?info_name $=$ social_unrest_table\&page $=$ noads $\& r f=0(23.01 .2015)$.

Scorpio Partnership (2012), The Scorpio Partnership Private Banking Benchmark. London: Scorpio Partnership, www.scorpiopartnership.com/knowledge.php (2.01.2014).

Solnik B.H. (1974), Why Not Diversify Internationally Rather than Domestically?, "Financial Analysts Journal" vol. 30, no. 4, pp. 48-52, 54.

stooq.pl (2014), Bielsko-Biała, stooq.pl (2.01.2014).

United Nations (2012)., Statistics Division. New York: United Nations, http://unstats.un.org/unsd/demographic/ products/socind/default.htm (23.01.2015).

World Bank (2013), GDP - 2013. Washington: World Bank, http://data.worldbank.org/data-catalog/GDP-rankingtable (23.01.2015). 


\section{MIĘDZYNARODOWE PORTFOLIO RÓŻNORODNOŚĆ:}

\section{PRAKTYCZNE PODEJŚCIE DO ZARZĄDZANIA MAJĄTKIEM}

Streszczenie: $\mathrm{Cel}$ - W artykule wskazano, że obecna międzynarodowa dywersyfikacja portfela w dobie globalizacji jest użytecznym narzędziem, które pozwala na budowanie portfela inwestycyjnego oferującego stosunkowo wysokie stopy zwrotu (które są zatwierdzone jako punkt odniesienia) z dopuszczalnym ryzykiem.

Slowa kluczowe: decyzje portfolio, giełda, inwestycje międzynarodowe

\section{Citation}

Halicki M., Uphaus A. (2015), International Portfolio Diversification: A Practical Approach to Wealth Management, Zeszyty Naukowe Uniwersytetu Szczecińskiego nr 855, „Finanse, Rynki Finansowe, Ubezpieczenia” nr 74, t. 1, Wydawnictwo Naukowe Uniwersytetu Szczecińskiego, Szczecin, s. 421-432; www.wneiz.pl/frfu. 